\title{
$\frac{100}{\mathrm{LiT}}$ RPESS
}

\section{POSTECPOWANIE DOWODOWE NA ROZPRAWIE GEÓWNEJ BEZ UDZIAŁU OSKARŻONEGO W ŚWIETLE ART. 378A KODEKSU POSTĘPOWANIA KARNEGO A STANDARDY RZETELNEGO PROCESU}

\section{WSTĘP}

W wyniku wejścia w życie ustawy z 19 lipca 2019 r. ${ }^{1}$ do Kodeksu postępowania karnego wprowadzony został przepis art. 378a. Zasadniczym celem zmian zaproponowanych w rządowym projekcie tej ustawy było „stworzenie warunków do szybszego załatwiania spraw w postępowaniu sądowym”" Przepis art. 378a k.p.k. ${ }^{3}$ zakłada możliwość przeprowadzenia postępowania dowodowego na rozprawie głównej bez udziału oskarżonego lub jego obrońcy. Jeszcze na etapie prac legislacyjnych przepis ten budził kontrowersje. Sygnalizowane były one m.in. przez Sąd Najwyższy ${ }^{4}$, który wskazał, że przepis ten budzi waţpliwości w świetle przepisów Konstytucji RP oraz Konwencji o ochronie praw człowieka ${ }^{5}$;

* Renata Badowiec, Uniwersytet Mikołaja Kopernika w Toruniu r.badowiec@umk.pl,https://orcid.org/0000-0001-7912-1363

1 Ustawa z 19 lipca 2019 r. o zmianie ustawy - Kodeks postępowania karnego oraz niektórych innych ustaw, Dz. U. 2019, poz. 1964 (dalej jako: k.p.k.).

2 Projekt ustawy o zmianie ustawy - Kodeks postępowania karnego oraz niektórych innych ustaw z 21 lutego 2019 r.: 26, <http://orka.sejm.gov.pl/Druki8ka.nsf/0/A617BC771FDAE095C12583AC004875E9/\%24File/3251.pdf> [dostęp: 13.01.2021].

${ }^{3}$ Ustawa z 6 czerwca 1997 r. - Kodeks postępowania karnego, t. jedn.: Dz. U. 2020, poz. 30 ze zm. (dalej jako: k.p.k.).

${ }^{4}$ Uwagi SN do rządowego projektu ustawy o zmianie ustawy - Kodeks postępowania karnego oraz niektórych innych ustaw: 8-13, <http://orka.sejm.gov.pl/Druki8ka.nsf/0/F5BF27E91FA57F7DC12583C3002E9D24/\%24File/3251-002.pdf> [dostęp: 13.01.2021].

${ }^{5}$ Konwencja o ochronie praw człowieka i podstawowych wolności sporządzona w Rzymie z 4 listopada 1950 r., zmieniona następnie Protokołami nr 3, 5 i 8 oraz uzupełniona Protokołem nr 2, Dz. U. 1993, Nr 61, poz. 284 (dalej jako: EKPC). 
Okręgową Radę Adwokacką w Warszawie ${ }^{6}$, która przyjęła, że jako absolutnie niezgodne z powyżej wskazanymi standardami trzeba ocenić zmiany w zakresie możliwości prowadzenia rozprawy głównej podczas usprawiedliwionej nieobecności oskarżonego czy jego obrońcy, w szczególności mogącej wynikać z okoliczności uznawanych na przykład za vis maior; czy Rzecznika Praw Obywatelskich $(\mathrm{RPO})^{7}$, który zajął stanowisko, że uregulowanie należy ocenić jako skrajnie godzące w gwarancje procesowe przysługujące oskarżonemu, w szczególności przysługujące mu prawo do obrony.

W związku z przywołanymi wyżej opiniami, w których wskazane zostało, że wprowadzona regulacja może nie czynić zadość określonym gwarancjom przysługującym oskarżonemu w postępowaniu karnym, celem artykułu jest analiza i ocena nowej regulacji, tj. przepisu art. 378a k.p.k. wprowadzonego nowelizacja z 19 lipca 2019 r., w kontekście standardów rzetelnego procesu. W opracowaniu powołane i omówione zostaną standardy: konstytucyjny, unijny oraz strasburski, a następnie na ich podstawie przeanalizowana zostanie treść przepisu art. 378a k.p.k. Należy bowiem odpowiedzieć na pytanie, czy obowiązująca już regulacja czyni zadość wskazanym tu standardom. Ponadto zagadnienie to jest istotne ze względu na prawo oskarżonego do obrony, które jest fundamentem procesu karnego i ze względu na jego zakorzenienie w zasadzie demokratycznego państwa prawnego, powinno być gwarantowane w każdym postępowaniu, które ma charakter represyjny ${ }^{8}$.

\section{STANDARDY DOTYCZĄCE OBECNOŚCI OSKARŻONEGO NA ROZPRAWIE}

Na gruncie polskiego ustawodawstwa zasadą jest, że oskarżony ma prawo do obrony. Jest ono bowiem nie tylko fundamentalną zasadą procesu karnego, lecz także elementarnym standardem demokratycznego państwa prawnego. Za najistotniejsza gwarancję prawa do obrony należy uznać możliwość przedstawienia własnego stanowiska w sprawie i ustosunkowania się do sformułowanych zarzutów. Jest to jednak niemożliwe wówczas, gdy postępowanie przed sądem toczy się bez osoby, której zarzuty dotyczą ${ }^{9}$. Konstytucyjne prawo do obrony należy rozumieć szeroko. W tej mierze w ustawach karnych musza być przewidziane odpowiednie gwarancje, a stwierdzenie naruszenia prawa do obrony wywołuje określone konsekwencje prawnoprocesowe ${ }^{10}$. Zasada prawa

${ }^{6}$ Stanowisko Sekcji Prawa i Postępowania Karnego przy Okręgowej Radzie Adwokackiej w Warszawie do projektu zmian kodeksu postępowania karnego z 4.12.2018 r.: s. 5-7, <https:// www.ora-warszawa.com.pl/aktualnosci/wiadomosci/stanowisko-ora-w-warszawie-do-projektu-zmian-kodeksu-postepowania-karnego-z-dnia-4-grudnia-2018-roku/> [dostęp: 13.01.2021].

7 Uwagi Rzecznika Praw Obywatelskich dotyczące projektu zmiany ustawy - Kodeks postępowania karnego oraz niektórych innych ustaw: 2-5, <https://legislacja.rcl.gov.pl/docs//2/1231880 6/12554733/12554736/dokument377912.pdf.> [dostęp: 13.01.2021].

8 Wyrok TK z 28 listopada 2007 r., K 39/07, Legalis nr 89229.

${ }^{9}$ Wyrok TK z 28 listopada 2007 r., K 39/07, Legalis nr 89229.

10 Orzeczenie TK z 20 października 1992 r., K 1/92, Legalis nr 10133. 
do obrony w szerokim rozumieniu oznacza, że ogranicza się ona nie tylko do posiadania przez oskarżonego obrońcy, ale obejmuje także całokształt instytucji prawnych, które przewidziane są w ustawach karnych, służacych oskarżonemu w dowodzeniu jego niewinności lub wskazywaniu na okoliczności mogące mieć wpływ na orzeczenie o winie i w konsekwencji na wymiar kary ${ }^{11}$. Zapewnienie standardu rzetelnego procesu wymaga, aby sąd, jeżeli nawet skorzystał z dopuszczalnych ustawa odstępstw od określonych zasad procesowych, miał jednak wzgląd na potrzebę zachowania realizacji innych, takich jak właśnie prawo oskarżonego do obrony ${ }^{12}$. Zgodnie z treścią art. 42 Konstytucji $\mathrm{RP}^{13}$ każdy, przeciwko komu prowadzone jest postępowanie karne, ma prawo do obrony we wszystkich stadiach postępowania. W szczególności może on wybrać obrońcę lub korzystać z obrony z urzędu na zasadach określonych w ustawie. Przepis art. 42 ust. 2 Konstytucji RP ustanawia więc konstytucyjną zasadę prawa do obrony. Konstytucyjne, gwarancyjne ujęcie prawa do obrony ma bezpośredni wpływ na kształt zasady prawa do obrony w procedurze karnej. Oskarżony ma prawo do obrony we wszystkich stadiach procesu, za pomoca wszelkich przysługujących mu środków procesowych. Nie można więc mówić o prawie do obrony tam, gdzie nie występuje oskarżony jako strona postępowania karnego ${ }^{14}$. Warto także zwrócić uwagę na konstytucyjny standard prawa do sądu, oparty na art. 45 ust. 1 Konstytucji RP. Odgrywa on coraz większa rolę w procesie karnym. Uniwersalny standard określony w tej regulacji wskazuje na procesową pozycję jednostki, której sprawa podlega rozpoznaniu przez sąd. Na konstytucyjne prawo do sądu składają się w szczególności: prawo do dostępu do sądu, czyli prawo uruchomienia procedury przed sądem - organem o określonej charakterystyce (niezależnym, bezstronnym i niezawisłym); prawo do odpowiedniego ukształtowania procedury sądowej, zgodnie z wymogami sprawiedliwości i jawności, oraz prawo do wyroku sądowego, czyli prawo do uzyskania wiążącego rozstrzygnięcia danej sprawy przez sąd ${ }^{15}$.

W przypadku standardu unijnego dotyczącego udziału oskarżonego w rozprawie główniej trzeba wskazać na dyrektywę Parlamentu Europejskiego i Rady (UE) 2016/343 z 9 marca 2016 r. w sprawie wzmocnienia niektórych aspektów domniemania niewinności i prawa do obecności na rozprawie w postępowaniu karnym ${ }^{16}$. Z samej preambuły dyrektywy 2016/343 wynika, że prawo do rzetelnego procesu sądowego stanowi jedna z podstawowych zasad społeczeństwa demokratycznego, natomiast prawo podejrzanych oraz oskarżonych do obecności na rozprawie wywodzi się z tego prawa i powinno być zapewnione w całej Unii Europejskiej. Co istotne, jeżeli z przyczyn nieza-

11 Wiliński (2009): 330.

${ }^{12}$ Wyrok SN z 2 marca 2006 r., III KK 466/04, OSNwSK 2006, nr 1, poz. 476.

${ }^{13}$ Konstytucja Rzeczypospolitej Polskiej z 2 kwietnia 1997 r. uchwalona przez Zgromadzenie Narodowe w dniu 2 kwietnia 1997 r., przyjęta przez Naród w referendum konstytucyjnym w dniu 25 maja 1997 r., podpisana przez Prezydenta Rzeczypospolitej Polskiej w dniu 16 lipca 1997 r., Dz. U. 1997, Nr 78, poz. 483 ze zm.

${ }^{14}$ Wiliński (2011): 179.

15 Wyroki TK: z 9 czerwca 1998 r., K 28/97, Legalis nr 10441; z 11 czerwca 2002 r., SK 5/02, Legalis $\mathrm{nr} 54428$.

${ }^{16}$ Dz. Urz. UE L z 11 marca 2016 r. (dalej jako: dyrektywa 2016/343). 
leżnych od podejrzanych czy oskarżonych nie są oni w stanie stawić się na rozprawie, powinni mieć zapewnioną możliwość zwrócenia się o wyznaczenie nowego terminu rozprawy w ramach czasowych przewidzianych prawem krajowym. W pewnych okolicznościach powinna istnieć możliwość wydania orzeczenia w przedmiocie winy lub niewinności podejrzanego lub oskarżonego, nawet jeżeli jest on nieobecny na rozprawie. Dotyczyć to powinno sytuacji, gdy podejrzany lub oskarżony nie stawia się na rozprawie, pomimo że został on we właściwym czasie poinformowany o tej rozprawie, a także o konsekwencjach niestawiennictwa. Wynika z tego, że oskarżony, mimo właściwego zawiadomienia go o terminie rozprawy, swoim zachowaniem jasno wskazuje, że nie wyraża woli wzięcia w niej udziału. Poinformowanie podejrzanego lub oskarżonego o rozprawie należy rozumieć jako doręczenie mu wezwania do rąk własnych lub przekazanie mu inną drogą urzędowej informacji o terminie i miejscu rozprawy w taki sposób, który umożliwia dowiedzenie się o tej rozprawie. Podejrzanego lub oskarżonego należy również poinformować o konsekwencjach ewentualnego niestawiennictwa, w szczególności o tym, że orzeczenie może zostać wydane pod jego nieobecność na rozprawie. Druga możliwościa przeprowadzenia rozprawy pod nieobecność oskarżonego jest ta, kiedy oskarżonego powiadomiono o terminie rozprawy, ale jest on reprezentowany przez wybranego przez siebie lub wyznaczonego z urzędu obrońcę. W sytuacji, w której nie zostaną zachowane wyżej wskazane warunki, państwa członkowskie obowiązane są do zapewnienia, aby oskarżony miał prawo do wznowienia postępowania lub skorzystania z innego środka prawnego, który umożliwia ponowne rozpoznanie sprawy co do jej istoty, w tym ocenę dowodów, a także może prowadzić do uchylenia pierwotnego orzeczenia. Państwa członkowskie zapewniaja więc oskarżonym prawo do obecności oraz skutecznego udziału, a nadto do korzystania z prawa do obrony.

W przypadku aktów prawa międzynarodowego udział oskarżonego w rozprawie głównej gwarantuje przede wszystkim art. 6 EKPC, który stanowi m.in., że każdy ma prawo do sprawiedliwego oraz publicznego rozpatrzenia jego sprawy w rozsądnym terminie przez niezawisły i bezstronny sąd ustanowiony ustawa przy rozstrzyganiu o jego prawach i obowiązkach o charakterze cywilnym albo o zasadności każdego oskarżenia w wytoczonej przeciwko niemu sprawie karnej. Warto wskazać, że również z treści art. 14 Międzynarodowego paktu praw obywatelskich i politycznych ${ }^{17}$ wynika, iż każdy oskarżony o popełnienie przestępstwa ma prawo, na zasadach pełnej równości, do obecności na rozprawie, bronienia się osobiście lub przez obrońcę przez siebie wybranego oraz do otrzymania informacji, jeżeli nie posiada informacji o istnieniu tego prawa, a także posiadania obrońcy wyznaczonego dla niej w każdym przypadku, kiedy interesy sprawiedliwości tego wymagaja, bez ponoszenia kosztów obrony w przypadkach, kiedy oskarżony nie posiada dostatecznych środków na ich pokrycie.

17 Międzynarodowy pakt praw obywatelskich i politycznych otwarty do podpisu w Nowym Jorku dnia 19 grudnia 1966 r., Dz. U. 1977, Nr 38, poz. 167 (dalej jako: MPPOiP). 
Europejski Trybunał Praw Człowieka (ETPC) szczególny nacisk kładzie na osobiste uczestnictwo oskarżonego w postępowaniu karnym, gdyż jego wypowiedzi oraz ogólne wrażenie, jakie wywiera na sądzie, odgrywają bardzo ważną rolę. W orzecznictwie ETPC podkreśla się, że konieczność stawiennictwa oskarżonego na rozprawie zależy jednak od systemu prawnego konkretnego państwa. W systemie common law wymagana jest osobista obecność oskarżonego w sądzie, która ma na celu realizację zasad równości stron oraz kontradyktoryjności, natomiast w systemach kontynentalnych przyjmuje się zwykle, że obecność oskarżonego na rozprawie co do zasady jest jego prawem, a nie obowiązkiem ${ }^{18}$. Zagwarantowanie oskarżonemu prawa do udziału w rozprawie przed sądem I instancji jest niezbędne, natomiast w rozprawie odwoławczej konieczne jedynie, gdy sąd odwoławczy kontroluje wyrok sądu I instancji nie tylko pod względem zarzutów odnoszacych się do sfery prawa, lecz także pod kątem zarzutów dotyczących ustaleń faktycznych. Obecność oskarżonego na rozprawie jest w takich sytuacjach niezbędna, a oskarżony pozbawiony wolności powinien być sprowadzony na rozprawę, gdy tego się domaga $^{19}$.

Postępowanie pod nieobecność oskarżonego jest dopuszczalne, gdy rozprawa prowadzona jest zgodnie z zasadą kontradyktoryjności. Obecność oskarżonego nie jest także wymagana na części rozprawy dotyczącej czynów, do których popełnienia oskarżony się przyznał. Na gruncie art. 6 EKPC dopuszczalne jest ponadto rozpoznanie sprawy pod nieobecność oskarżonego, jeżeli obecny był jego obrońca, w szczególności gdy wymagał tego interes wymiaru sprawiedliwości oraz gdy oskarżony nie mógł przybyć na rozprawę ${ }^{20}$. Z orzecznictwa ETPC wynika więc, że istnieje możliwość przeprowadzenia rozprawy pod nieobecność oskarżonego. Sytuacje takie wymagaja jednak dochowania należytej staranności, która ma na celu prawidłowe powiadomienie oskarżonego o terminie rozprawy ${ }^{21}$. Proces taki jest również możliwy (i jednocześnie jest zgodny ze standardami rzetelnego procesu), gdy oskarżony rezygnuje z prawa do bycia obecnym na rozprawie. Jego oświadczenie woli musi jednak być wyrażone jednoznacznie i w sposób niebudzący wątpliwości co do tego, iż był świadomy zarówno jego treści, jak i skutków prawnych, a samo niestawiennictwo oskarżonego na rozprawie w żadnym wypadku nie może być interpretowane jako zrzeczenie się tego prawa ${ }^{22}$. Oskarżonego nie może obciążać obowiązek udowodnienia, że nie usiłował uniknać wymiaru sprawiedliwości lub tego, iż jego nieobecność wynikała z siły wyższej ${ }^{23}$.

18 Hermeliński, Nita-Światłowska (2019): 23.

19 Hermeliński, Nita-Światłowska (2019): 24.

20 Urbaniak (2003): 65.

${ }_{21}$ Zob. np. wyroki ETPC: z 25 listopada 1997 r., 69/1996/688/880, Zana v. Turcja, Legalis nr 135369; z 26 maja 1988 r., 10563/83, Ektabani v. Szwecja, Lex nr 81055; z 24 marca 2005 r., 9808/02, Stoichkov v. Butgaria, Lex nr 149013.

22 Zob. np. wyroki ETPC: z 12 lutego 1985 r., 9024/80, Colozza v. Wtochy, Lex nr 80999; z 23 listopada 1993 r., 14032/88, Poitrimol v. Francja, Lex nr 80554; z 27 maja 2004 r., 46549/99, Yavuz v. Austria, Lex nr 125981.

${ }^{23}$ Wyrok ETPC z 12 lutego 1985 r., 9024/80, Colozza v. Włochy. 
Na uwagę zasługuje wyrok EKPC z 12 października 1992 r. ${ }^{24}$, w którym wskazano, że szybkość postępowania nie może stanowić przeszkody we właściwym funkcjonowaniu wymiaru sprawiedliwości. Przez pojęcie właściwego funkcjonowania wymiaru sprawiedliwości należy rozumieć przede wszystkim troskę o to, aby rozstrzygnięcie oparte było na prawidłowo poczynionych ustaleniach faktycznych, które dokonane zostały przy zachowaniu wymogów rzetelności postępowania ${ }^{25}$. Trybunał uznał również, że szybkość postępowania nie może odbywać się kosztem czynionych ustaleń faktycznych ${ }^{26}$. Trybunał stwierdził także, że przy rozstrzyganiu, czy postępowanie jako całość było rzetelne, należy zwrócić uwagę, czy respektowane były prawa obrony, a w szczególności konieczne jest sprawdzenie, czy skarżącemu dano możliwość zakwestionowania wiarygodności dowodów i przeciwstawienia się ich wykorzystaniu ${ }^{27}$. Fundamentalnym aspektem prawa do rzetelnego procesu jest to, że postępowanie karne powinno być kontradyktoryjne, a także powinna istnieć równość broni między oskarżeniem a obroną ${ }^{28}$. Dowody powinny być zasadniczo przedstawione w obecności oskarżonego na publicznej rozprawie w myśl kontradyktoryjnego sporu. Prawo do kontradyktoryjnego procesu w sprawie karnej oznacza, że zarówno oskarżenie, jak i obrona mają mieć możliwość zapoznania się oraz odniesienia do oświadczeń złożonych przez drugą stronę i przedstawionych przez nią dowodów. Nie jest to jednak równoznaczne z tym, że obie strony muszą mieć jednakowa pozycję procesową. Zasada kontradyktoryjności daje możliwość zapoznania się z dowodami zgromadzonymi w procesie oraz oświadczeniami składanymi przez drugą stronę. Prawo krajowe może zapewnić realizację zasady kontradyktoryjności w różny sposób, jednak niezależnie od użytej metody musi ona zapewniać, że druga strona zostanie poinformowana o złożonych wnioskach i będzie miała realną możliwość ustosunkowania się do nich ${ }^{29}$. W związku z tym zarówno oskarżyciel, jak i oskarżony oraz jego obrońca muszą mieć prawo do uzyskania wiedzy o stanowisku strony przeciwnej, a także mieć dostęp do materiału dowodowego przedstawionego przez drugą stronę ${ }^{30}$.

Analizując zagadnienie udziału oskarżonego w rozprawie, należy także odnieść się do zasady, że skazanie w sprawie nie może być oparte wyłacznie albo w decydującej mierze na oświadczeniach pochodzących od osoby, której oskarżony nie miał możliwości przesłuchać. Europejski Trybunał Praw Człowieka stwierdził, że zasada ta nie ma charakteru absolutnego. Każdorazowo konieczne jest bowiem dokonanie szczególnie wnikliwej oceny sytuacji i rozważenie, czy istniały silne gwarancje proceduralne, w tym dotyczace oceny wiarygodności źródła dowodowego, równoważące niebezpieczeństwa związa-

${ }^{24}$ Wyrok ETPC z 12 października 1992 r., 12919/87, Boddaert v. Belgia, Lex nr 81249.

${ }^{25}$ Kłak (2012): 30.

${ }^{26}$ Zob. np. wyroki ETPC: z 23 lutego 2006 r., 46317/99, Ognyanov $i$ Choban v. Butgaria, Lex nr 172031; z 21 lutego 2006 r., 52390/99, Şeker v. Turcja, Lex nr 172043; z 6 października 2005 r., 28299/95, Haran v. Turcja, Lex nr 157827.

${ }^{27}$ Wyrok ETPC z 12 czerwca 2008 r., 32092/02, Yaramenko v. Ukraina, Lex nr 398935.

${ }^{28}$ Wyrok ETPC z 16 lutego 2000 r., 2890/95, Rowe i Davis v. Zjednoczone Królestwo, Lex nr 76903.

${ }^{29}$ Lach (2018): 72.

${ }^{30}$ Jasiński (2019): 1870. 
ne $\mathrm{z}$ oparciem rozstrzygnięcia na takim dowodzie. Ich istnienie warunkuje uznanie postępowania za spełniające wymóg rzetelności ${ }^{31}$. W orzecznictwie po wydaniu wyroku w sprawie Al-Khawaja $i$ Tahery przeciwko Zjednoczonemu Królestwu Trybunat wskazał, że w przypadku stwierdzenia naruszenia któregokolwiek z powyższych wymogów nie następuje automatyczne pogwałcenie standardu konwencyjnego rzetelności proceduralnej. To, czy dojdzie do naruszenia EKPC, oceniane jest w ramach indywidualnych okoliczności danej spra$\mathrm{wy}^{32}$. Wyjątki od obecności oskarżonego podczas publicznego rozpatrzenia sprawy są możliwe, ale nie mogą naruszać uprawnień składających się na prawo do obrony, które zasadniczo wymagaja, aby oskarżonemu zapewnić adekwatna i stosowną możliwość konfrontacji oraz zadania pytań świadkowi zeznającemu przeciwko niemu czy też podczas składania zeznań przez świadka ${ }^{33}$.

Z wyżej przywołanych regulacji oraz orzeczeń ETPC wynika, że obecność oskarżonego na rozprawie nie jest wymagana w każdym układzie procesowym, jednak możliwość jego udziału w rozprawie musi być zapewniona przez poszczególne państwa. W postępowaniu karnym zagwarantowane i respektowane powinny być także zasady: kontradyktoryjności oraz równości broni, aby stwierdzić, że mimo nieobecności oskarżonego na rozprawie proces przeprowadzony był w sposób odpowiadajacy standardom rzetelnego procesu. Warto również podkreślić, że zarówno w aktach prawnych, jak i w orzecznictwie ETPC jedna z sytuacji, gdy dopuszczalne jest przeprowadzenie rozprawy pod nieobecność oskarżonego, jest ta, w której sam oskarżony rezygnuje z przysługującego mu uprawnienia. Uwaga ta jest istotna ze względu na rozważania, które podjęte zostaną w kontekście art. 378a k.p.k.

\section{POSTĘPOWANIE DOWODOWE BEZ UDZIALU OSKARŻONEGO LUB OBROŃCY W ŚWIETLE ART. 378A KODEKSU POSTĘPOWANIA KARNEGO}

Poważne wątpliwości w świetle standardu rzetelnego procesu stanowi rozwiązanie ujęte w art. 378a k.p.k., co zostało już wskazane we wstępie artykułu. W uzasadnieniu projektu ustawy o zmianie ustawy - Kodeks postępowania karnego oraz niektórych innych ustaw projektodawca wskazał, że sytuacja niebudzącą wątpliwości jest ta, podczas której w razie usprawiedliwionego niestawiennictwa na rozprawie uprawnionych osób nie można jej kontynuować i powinna ona ulec odroczeniu lub przerwaniu. Jego zdaniem nie znaczy to jednak, by można było wykluczyć w takim wypadku jedynie przeprowadzenie

${ }^{31}$ Wyrok ETPC z 15 grudnia 2011 r., 26766/05, 22228/06, Al-Khawaja i Tahery v. Zjednoczone Królestwo, Lex nr 1100193.

32 Jasiński (2019): 1887.

33 Wyrok ETPC z 15 grudnia 2011 r., 26766/05, 22228/06, Al-Khawaja i Tahery v. Zjednoczone Królestwo, <https://www.echr.coe.int/documents/guide_art_6_criminal_eng.pdf> [dostęp: 13.01.2021]. 
dowodów, zwłaszcza przesłuchując osoby, które stawiły się na rozprawę. Zabezpieczenie gwarancji procesowych oskarżonego ma więc zapewnić regulacja, na podstawie której - w razie złożenia umotywowanego wniosku przez uczestnika, który z usprawiedliwionych przyczyn nie stawił się na rozprawę - dowód ten będzie należało przeprowadzić ponownie w zakresie, w którym nastapiło naruszenie tych gwarancji przez przesłuchanie tej osoby pod nieobecność uprawnionego. W opinii projektodawcy taka zmiana respektuje zasadę prawa do obrony przez umożliwienie przeprowadzenia dowodu w obecności oskarżonego i jego obrońcy. Gwarancyjnym unormowaniem ma być również przepis, że jeżeli oskarżony lub obrońca stawi się na kolejny termin rozprawy, poucza się go o możliwości złożenia wniosku o uzupełniające przeprowadzenie dowodu przeprowadzonego podczas jego nieobecności, a także umożliwia się mu wypowiedzenie się co do tej kwestii ${ }^{34}$. W uzasadnieniu projektu ustawy - Kodeks postępowania karnego oraz niektórych innych ustaw powołano się na praktykę, zgodnie z którą istotnym czynnikiem mającym wpływ na przedłużanie się czasu trwania postępowań jest konieczność odraczania oraz przerywania rozpraw w sytuacji usprawiedliwionej nieobecności oskarżonych i obrońców. Takie sytuacje, zdaniem ustawodawcy, obok przewlekłości postępowania prowadzą do dużych kosztów społecznych i finansowych. Ustawodawca zwrócił także uwagę na fakt, że dany dowód może mieć różne znaczenie dla ochrony interesów procesowych strony, stąd też nie zawsze nieobecne strony będą żądały ponownego jego przeprowadzenia.

Przepis art. 378a k.p.k. wprowadzony ustawą z 19 lipca 2019 r. o zmianie ustawy - Kodeks postępowania karnego oraz niektórych innych ustaw należy ocenić jako sprzeczny z obowiązującymi standardami rzetelnego procesu. Osobiste stawiennictwo oskarżonego w postępowaniu przed sądem I instancji ma bowiem kluczowe znaczenie, zwłaszcza w zakresie postępowania dowodowego. Pomijając nawet ten fakt, należy jednak wskazać na szereg błędnych rozwiązań zawartych w treści art. 378a k.p.k. Po pierwsze, sąd ma możliwość przeprowadzenia postępowania pod nieobecność oskarżonego, nawet gdy ten należycie usprawiedliwi swoje niestawiennictwo. Nie ulega wątpliwości, że w sytuacji, w której oskarżony wyraża chęć udziału w rozprawie i chce tym samym realizować swoje prawo do obrony (w szerokim znaczeniu tego słowa), sąd nie powinien przeprowadzać pod jego nieobecność postępowania dowodowego. Watpliwości budzi również sformułowanie, że sąd ma możliwość przeprowadzenia postępowania dowodowego pod nieobecność oskarżonego również w przypadku, gdy jeszcze nie złożył on wyjaśnień. Ponownie w kontekście chęci udziału oskarżonego w rozprawie należałoby jednak respektować porządek czynności procesowych wyznaczonych przepisami k.p.k., gdzie pierwsza czynnością po zwięzłym przedstawieniu zarzutów oskarżenia jest przesłuchanie oskarżonego na rozprawie. Wydaje się, że w tej sytuacji przeprowadzenie postępowania dowodowego bez uzyskania wyjaśnień oskarżone-

${ }^{34}$ Druk nr 3251: 44-45, <http://orka.sejm.gov.pl/Druki8ka.nsf/0/A617BC771FDAE095C 12583AC004875E9/\%24File/3251.pdf> [dostęp: 13.01.2021]. 
go narusza standard rzetelnego procesu ${ }^{35}$. Następnie należy zwrócić uwagę na uprawnienie oskarżonego do złożenia wniosku o uzupełniajace przeprowadzenie dowodu przeprowadzonego pod jego nieobecność. We wniosku tym oskarżony ma obowiązek wykazać, że sposób przeprowadzenia dowodu pod jego nieobecność naruszał gwarancje procesowe, a w szczególności prawo do obrony. To rozwiązanie budzi poważne wątpliwości, ponieważ oskarżony, który osobiście nie uczestniczył w czynnościach przeprowadzanych na rozprawie, może mieć problemy z udowodnieniem tego, że przeprowadzone postępowanie dowodowe nastapiło z naruszeniem gwarancji procesowych. Następną kwestią jest fakt, że to sąd uwzględnia wniosek i w jego opinii przeprowadzone postępowanie dowodowe mogło być niewadliwe i nie naruszało gwarancji procesowych. Ostatnim zastrzeżeniem w kontekście możliwości złożenia wniosku jest to, że nawet gdy sąd go uwzględni, to postępowanie dowodowe zostanie przeprowadzone wyłącznie uzupełniająco. Wydaje się, że takie rozwiązania wprowadzone przez ustawodawcę nie dość, że naruszają standardy rzetelnego procesu i prawo do obrony oskarżonego (w szczególności takiego, który swoja postawą wskazuje, że chce uczestniczyć w prowadzonym przeciwko niemu postępowaniu karnym), to dodatkowo mogą doprowadzić do przedłużenia postępowania karnego, a ponowne przeprowadzenie postępowania dowodowego i tak nastapi wyłącznie uzupełniająco. Wątpliwości budzi różnica między $§ 1$ i $§ 3$ art. 378a k.p.k. Sąd może przeprowadzić postępowanie dowodowe pod jego nieobecność (nawet jeżeli zostanie należycie usprawiedliwiona), ale już w stosunku do terminu złożenia wniosku o uzupełniajace przeprowadzenie dowodu sąd musi wziąc pod uwagę, że może on być złożony najpóźniej na kolejnym terminie rozprawy, o którym był należycie zawiadomiony przy jednoczesnym braku procesowych przeszkód do jego stawiennictwa. Ponadto należy podkreślić, że zgodnie z treścią przepisu art. 378a k.p.k. z obowiązaniem oskarżonego i jego obrońcy do wykazania, że doszło do ewentualnego naruszenia prawa do obrony, łączy się ustanowienie przez ustawodawcę przepisu, zgodnie z którym niezłożenie wniosku o uzupełniające przeprowadzenie dowodu w terminie wskazanym w art. 378a $§ 3$ k.p.k. powoduje wygaśnięcie prawa do jego złożenia i niedopuszczalność podniesienia tej kwestii jako zarzutu odwoławczego ${ }^{36}$. Takie rozwiązanie również trzeba określić jako zagrażające podstawowym gwarancjom przysługującym oskarżonemu w postępowaniu karnym.

Oczywiście wskazać trzeba, że sama możliwość przeprowadzenia, w wyjątkowych sytuacjach, czynności dowodowych pod nieobecność oskarżonego i jego obrońcy, zwłaszcza jeżeli na termin rozprawy stawili się świadkowie, nie stanowi przeszkody, chociaż niewątpliwie osłabia gwarancje wynikające z prawa do obrony. Istotne jest jednak zapewnienie mechanizmów, które pozwalałyby oskarżonemu i jego obrońcy na uniknięcie negatywnych skutków, które byłyby konsekwencją realizacji danej czynności pod nieobecność oskarżonego lub

${ }^{35}$ Uwagi SN do rządowego projektu ustawy o zmianie ustawy - Kodeks postępowania karnego oraz niektórych innych ustaw, <http://orka.sejm.gov.pl/Druki8ka.nsf/0/F5BF27E91FA57F7DC12583C3002E9D24/\%24File/3251-002.pdf> [dostęp: 13.01.2021].

${ }^{36}$ Hermeliński, Nita-Światłowska (2019): 30. 
obrońcy ${ }^{37}$. Rozwiązania przyjęte w treści art. 378a k.p.k. w żaden sposób nie sa jednak wystarczające. Jedyną przesłanką szczególną uzasadniającą zasadność wniosku o uzupełniające przeprowadzenie dowodu jest wykazanie, że jedynie sposób przeprowadzenia dowodu naruszał gwarancje procesowe, a w szczególności prawo do obrony. Należy zwrócić uwagę na fakt, że sposób przeprowadzania dowodu nie znajduje odzwierciedlenia w treści protokołu rozprawy. Dużo większe wątpliwości można mieć bowiem np. w stosunku do zakresu przeprowadzenia dowodu, tj. zadawanych pytań czy braku wnikliwości organu. Natomiast sam sposób jego przeprowadzenia, zwłaszcza wobec braku obecności oskarżonego lub jego obrońcy, jest w zasadzie niemożliwy do zweryfikowania ${ }^{38}$. W przypadku bowiem przesłuchania świadka udział ten daje oskarżonemu i obrońcy możliwość odebrania wrażeń oraz zgromadzenia spostrzeżeń związanych z przeprowadzeniem dowodu, pozwalających na zaznajomienie się nie tylko z treścią składanego oświadczenia dowodowego, lecz także np. sposobem komunikowania się świadka lub jego reakcją na pytania oraz reagowanie na bieżąco na jego wypowiedzi w drodze zadawania mu pytań ${ }^{39}$.

Należy podzielić pogląd, że rozwiązanie ujęte w treści art. 378a k.p.k. jest tak dalece niekorzystne dla oskarżonego i jego obrońcy, że faktycznie powoduje iluzoryczność kontradyktoryjnego procesu dowodowego w kontekście rzetelnego prawa do obrony ${ }^{40}$. Rozprawa główna jest jedynym momentem, w którym możliwe jest zweryfikowanie przez stronę bierną tez oskarżenia oraz zapoznanie z treścią dowodów, w szczególności zeznań świadków. Dlatego też niezwykle istotne jest zapewnienie prawa uczestnictwa oskarżonego i jego obrońcy w toku rozprawy głównej. Najczęściej to właśnie dynamika przesłuchania, konfrontowanie przekazywanych informacji, stawiane świadkowi pytania umożliwiają uzyskanie kluczowych informacji dla oceny wiarygodności świadka, innych dowodów, a na końcu dla przedmiotu procesu ${ }^{41}$. Przepis art. 378a k.p.k. prowadzi również do naruszenia zasady równości broni, regulacja ta dotyczy bowiem jedynie usprawiedliwionej nieobecności oskarżonego czy obrońcy. Natomiast nie pozwala ona na prowadzenie rozprawy w sytuacji, gdy nie stawi się na nia prokurator (tam gdzie jego stawiennictwo jest obowiązkowe). Należy ponownie zwrócić uwagę na dyrektywę 2016/343 - zgodnie z którą państwa członkowskie zapewniają podejrzanym lub oskarżonym prawo do obecności na rozprawie ${ }^{42}$.

Rzecznik Praw Obywatelskich również wskazał, że regulacja art. 378a k.p.k. może godzić w podstawowe gwarancje procesowe, w szczególności w prawo do obrony. Prawo do bycia obecnym na rozprawie stanowi bowiem jeden

37 Karlik (2020): 189.

38 Karlik (2020): 192.

39 Zagrodnik (2020): 1027-1028.

40 Ważny (2020): 1005.

41 Ważny (2020): 1006.

42 Stanowisko Sekcji Prawa i Postępowania Karnego przy Okręgowej Radzie Adwokackiej w Warszawie do projektu zmian Kodeksu postępowania karnego z 4.12.2018 r., <https://www. ora-warszawa.com.pl/aktualnosci/wiadomosci/stanowisko-ora-w-warszawie-do-projektu-zmian-kodeksu-postepowania-karnego-z-dnia-4-grudnia-2018-roku/> [dostęp: 13.01.2021]. 
z fundamentalnych atrybutów przewidzianego w art. 42 ust. 2 Konstytucji RP oraz art. 6 EKPC prawa do obrony. Możliwość „uzupełniającego” przeprowadzenia dowodu na wniosek oskarżonego lub obrońcy nie daje gwarancji zlikwidowania ewentualnych negatywnych skutków procesowych, które wynikaja z przeprowadzenia dowodu podczas nieobecności oskarżonego i jego obrońcy. Rzecznik wskazał na sytuacje, w których skorzystanie z tego uprawnienia nie będzie możliwe, np. brak możliwości ponownego przeprowadzenia dowodu z zeznań świadka, ponieważ jego przesłuchanie z pewnych względów będzie niemożliwe albo niewskazane ${ }^{43}$. Należy podzielić pogląd, że uregulowanie, które ujęte zostało w treści art. 378a $§ 5$ k.p.k., sugeruje, że (według ustawodawcy) sytuacja, w której prowadzono postępowanie dowodowe pomimo usprawiedliwionej nieobecności oskarżonego lub jego obrońcy, co do zasady nie wiąże się naruszeniem prawa do obrony ${ }^{44}$.

\section{WNIOSKI}

Prawo do obecności przy czynnościach procesowych stanowi element prawa do obrony. Ponadto do najważniejszych uprawnień związanych z prawem do obrony należy prawo do składania wyjaśnień, uczestniczenia w postępowaniu dowodowym, w szczególności zadawania świadkom i biegłym pytań, ustosunkowywania się do twierdzeń strony przeciwnej czy wypowiadania się co do każdej kwestii podlegającej rozstrzygnięciu. W najpełniejszym zakresie prawo do obrony może być realizowane przede wszystkim osobiście przez oskarżonego. W szczególności prawo to może być realizowane w toku rozpoznania sprawy przez sąd zarówno na rozprawie, jak i na posiedzeniu. Obecność oskarżonego przy rozpoznawaniu sprawy służy realizacji dalszych uprawnień związanych z jego obecnościa, jak złożenie wyjaśnień, uczestnictwo w postępowaniu dowodowym, zgłaszanie wniosków czy ustosunkowywanie się do twierdzeń strony przeciwnej ${ }^{45}$. Udział oskarżonego o popełnienie przestępstwa nie tylko jest niezbędny w celu jego obrony, ale również daje możliwość sądowi wysłuchania wszelkich oświadczeń osoby oskarżonej, które przygotowała. Warto wskazać, że osobiste uczestnictwo oskarżonego o popełnienie przestępstwa przy rozpoznawaniu sprawy umożliwia mu osobistą kontrolę przeprowadzonego postępowania dowodowego w kontekście rzetelności prowadzonego postępowania karnego ${ }^{46}$.

W kontekście wyrażonych wyżej wątpliwości należy uznać, że wykładnia językowa przepisu art. 378a k.p.k. może prowadzić do naruszania standardów rzetelnego procesu. Najistotniejszą bowiem gwarancją prawa do obrony

${ }^{43}$ Uwagi Rzecznika Praw Obywatelskich dotyczące projektu zmiany ustawy - Kodeks postępowania karnego oraz niektórych innych ustaw, <https://legislacja.rcl.gov.pl/docs//2/12318806/12 554733/12554736/dokument377912.pdf.> [dostęp: 13.01.2021].

44 Hermeliński, Nita-Światłowska (2019): 30.

45 Urbaniak (2003): 19.

46 Treschel (2005): 253. 
jest możliwość przedstawienia własnego stanowiska w sprawie i ustosunkowania się do sformułowanych zarzutów. Jest to jednak niemożliwe wówczas, gdy postępowanie przed sądem toczy się bez osoby, której zarzuty dotyczą ${ }^{47}$. W uzasadnieniu rządowego projektu znalazło się sformułowanie, że „niezmiernie ważne znaczenie w kontekście zapewnienia prawidłowego, terminowego i niezakłóconego biegu postępowania karnego jest, w ocenie projektodawców, przeciwdziałanie możliwości obstrukcji procesowej stron oraz zapobieganie zbędnemu powtarzaniu czynności dowodowych". Nie wydaje się, aby możliwość przeprowadzenia postępowania dowodowego, nawet jeżeli ma nastapić uzupełniająco, spełniała założenia projektodawców. W związku z tym, że przepis art. 378a k.p.k. już obowiązuje, należy zastosować możliwie najwęższą wykładnię warunku zastosowania art. 378a § 1 k.p.k., którym jest „szczególnie uzasadniony przypadek”. Trzeba więc przyjąć, że powinien swym zakresem obejmować wyłącznie takie przypadki, w których zachodzi niebezpieczeństwo, że w późniejszym czasie określonego dowodu nie da się przeprowadzić (np. ze względu na stan zdrowia świadka ${ }^{48}$. Interpretacja art. 378a k.p.k., która nie uwzględniałaby standardów rzetelnego procesu ani zasad demokratycznego państwa prawnego, stanowiłaby daleko idące naruszenia praw przysługujących oskarżonemu w postępowaniu karnym, w szczególności możliwości skorzystania z prawa do obrony. Sąd, który w konkretnej sytuacji procesowej będzie chciał skorzystać z regulacji art. 378a k.p.k., obowiązany będzie więc odnieść się do standardów rzetelnego procesu, aby nie doszło do osłabienia pozycji procesowej oskarżonego w postępowaniu karnym. Standardy poddane analizie w tym artykule skłaniają do wniosku, że właściwe w toku postępowania karnego powinno być wyznaczenie innego terminu czynności dowodowych, dla których właściwym forum jest rozprawa główna, w sytuacjach, w których oskarżony lub obrońca nie stawili się na niej z przyczyn usprawiedliwionych. Przewidziana więc w art. 378a k.p.k. możliwość przeprowadzenia czynności dowodowych podczas usprawiedliwionej nieobecności oskarżonego lub jego obrońcy jest nie do pogodzenia z obecnie obowiąujacymi standardami rzetelnego procesu, w tym przede wszystkim z treścią art. 6 EKPC, w którym określone zostały minimalne standardy prawa do obrony oraz prawa do sądu, wymagające urzeczywistnienia na gruncie wewnętrznych porządków prawnych państw stron Konwencji ${ }^{49}$.

Hermeliński, W., Nita-Światłowska, B. (2019). Orzekanie pod nieobecność oskarżonego a gwarancje wynikające z przepisów rangi ponadustawowej. Palestra 9: 14-31.

Jasiński, W. (2019). Prawo dowodowe w postępowaniu przed Międzynarodowym Trybunałem Karnym oraz Europejskim Trybunałem Praw Człowieka, [w:] J. Skorupka (red.), System prawa karnego procesowego. Tom 8. Część 2. Warszawa: 1870-1887.

Karlik, P. (2020). Przepisy ogólne o rozprawie głównej, [w:] K. Gajowniczek-Pruszyńska, P. Karlik, Kodeks postępowania karnego. Komentarz do ustawy z 19.7.2019 r., Warszawa: 182-193.

\footnotetext{
47 Wyrok TK z 28 listopada 2007 r., K 39/07, Legalis nr 89229.

48 Zagrodnik (2020): 1030.

49 Zagrodnik (2020): 1028.
} 
Kłak, C. (2012). Pojęcie skutecznego środka odwoławczego w odniesieniu do przewlekłości postępowania w rozumieniu art. 13 EKPC a polska skarga na przewlekłość postępowania karnego, [w:] P. Czubik, Z. Mach (red.), Hereditas Mercaturæ. Księga pamiątkowa dedykowana świętej pamięci Stanisławowi Miklaszewskiemu. Kraków: 27-62.

Lach, A. (2018). Rzetelne postępowanie dowodowe w sprawach karnych w świetle orzecznictwa strasburskiego. Warszawa.

Treschel, S. (2005). Human Rights in Criminal Proceedings. Oxford.

Urbaniak, M. (2003). Rozpoznawanie spraw pod nieobecność oskarżonego w polskim procesie karnym. Poznań-Kalisz.

Ważny, A. (2020). Przepisy ogólne o rozprawie głównej, [w:] A. Sakowicz (red.), Kodeks postępowania karnego. Komentarz. Warszawa: 983-1008.

Wiliński, P. (2009). Rzetelny proces karny w świetle Konstytucji i orzecznictwa Trybunału Konstytucyjnego, [w:] P. Wiliński (red.), Rzetelny proces karny. Warszawa: 303-349.

Wiliński, P. (2011). Proces karny w świetle Konstytucji. Warszawa.

Zagrodnik, J. (2020). Przepisy ogólne o rozprawie głównej, [w:] J. Skorupka (red.), Kodeks postępowania karnego. Komentarz. Warszawa: 993-1065.

\section{TAKING EVIDENCE AT A MAIN HEARING WITHOUT THE PARTICIPATION \\ OF THE ACCUSED IN THE LIGHT OF ARTICLE 378A OF THE CODE OF CRIMINAL PROCEDURE AND THE STANDARDS OF A FAIR TRIAL}

\section{Summary}

The aim of the article is to study a new regulation: the provision of Article 378a of the Code of Criminal Procedure (CCP), introduced with the amendment of 19 July 2019 in the context of fair trial standards. The right to defence, which is also an element of the fair trial standard, is vested in everyone from the moment when criminal proceedings are instituted against them until a final judgment is issued. It is important that the rights of defence must be procedural in order to be real and effective. The study refers to and discusses the following standards: constitutional, EU and Strasbourg, and then analyses the content of Article 378a of the CCP. The considerations lead to the conclusion that the possibility of taking evidence during the justified absence of the accused or his lawyer provided for in Article 378a of the CCP is incompatible with the current standards of a fair trial.

Keywords: right to defence; fair trial; amendment to the Code of Criminal Procedure; accused 
